\title{
PENGEMBANGAN MULTIMEDIA PEMBELAJARAN INTERAKTIF DENGAN MACROMEDIA AUTHORWARE 7.0 PADA MATAKULIAH KONSEP DASAR IPA
}

\author{
Adi Winanto, Mawardi, Atalya Agustin \\ Program Studi S1Pendidikan Guru Sekolah Dasar (PGSD) \\ FKIP - Universitas Kristen Satya Wacana
}

\begin{abstract}
ABSTRAK
Salah satu topik dalam materi dari mata kuliah Konsep Dasar IPA adalah tata surya. Salah satu kendala yang dihadapi yaitu penyajian tata surya hanya berupa gambar statis 2 dimensi. Penelitian pengembangan ini bertujuan untuk: 1) Mengembangkan multimedia pembelajaran interaktif dengan Macromedia Authorware 7.0 pada matakuliah Konsep Dasar IPA - Pokok Bahasan Tata Surya; 2) mengetahui hasil pembelajarannya, dan 3) menguji kelayakannya. Prosedur pengembangan dalam penelitian mengadaptasi model pengembangan menurut Dick \& Carey dan juga Nana Syaodih Sukmadinata (2007:184-185). Prosedur yang diadaptasi tersebut meliputi tiga tahap, yaitu: (1) tahap studi pendahuluan, (2) tahap penyusunan draft produk dan (3) tahap pengembangan dan evaluasi. Hasil yang diperoleh Multimedia interaktif dengan Macromedia Authorware 7.0 pada matakuliah Konsep Dasar IPA - Pokok Bahasan Tata Surya dapat dikembangkan dengan menyajikan animasi tentang tata surya dengan dilengkapi dengan data-data pendukung mengenai anggota tata surya tersebut. Hasil tes dari pembelajaran dengan menggunakan multimedia interaktif ini menunjukkan hasil yang baik. Hasil post tes rata-rata adalah 82.7 sedangkan hasil pre tes adalah 50.3. Multimedia interaktif ini layak untuk digunakan dalam pembelajaran. Rata-rata skor pada one to one evaluation adalah 4.2; pada small group evaluation adalah 4.1 dan pada field trial evaluation adalah 4.2 .
\end{abstract}

\section{PENDAHULUAN}

Konsep Dasar IPA merupakan salah satu mata kuliah keahlian berkarya (MKB) dalam struktur kurikulum S1 Pendidikan Guru Sekolah Dasar (PGSD) yang bertujuan untuk membekali calon guru SD untuk memahami konsep-konsep dasar Ilmu Pengetahuan Alam. Salah satu topik dalam materi dari mata kuliah Konsep Dasar IPA adalah tata surya. Topik ini membahas tentang planet-planet dan benda langit lainnya dari tata surya. Pengajar mengalami kesulitan menjelaskan kepada mahasiswa jika hanya menggunakan gambar statis 2 dimensi. Perlu dikembangkan media pembelajaran yang mampu memberikan gambaran/animasi yang jelas tentang tata surya. Salah satu media pembelajaran yang secara potensial dapat meningkatkan keaktifan dan kegairahan dalam belajar adalah pembelajaran menggunakan media interaktif dengan program Macromedia Authorware 7.0.

Salah satu software yang dapat membuat berbagai media seperti video, animasi, gambar, suara, dan sebagainya dengan cara yang mudah adalah Macromedia Authorware 7.0. Berdasarkan pemikiran di atas peneliti bermaksud melakukan Pengembangan Multimedia Pembelajaran Interaktif dengan Macromedia Authorware 7.0 pada Matakuliah Konsep Dasar IPA- Pokok Bahasan Tata Surya.

Berdasarkan latar belakang masalah penelitian di atas maka masalah yang diteliti di sini dapat dirumuskan sebagai berikut: 
1. Bagaimanakah pengembangan multimedia interaktif dengan Macromedia Authorware 7.0 pada matakuliah Konsep Dasar IPA - Pokok Bahasan Tata Surya?

2. Bagaimanakah hasil pembelajaran dengan menggunakan multimedia interaktif dengan Macromedia Authorware 7.0 pada Matakuliah Konsep Dasar IPA - Pokok tata surya?

3. Apakah pengembangan multimedia interaktif dengan Macromedia Authorware 7.0 pada Matakuliah Konsep Dasar IPA- Pokok Bahasan tata surya sesuai dengan kriteria kelayakan media pembelajaran?

Penelitian pengembangan ini bertujuan untuk:

1. Mengembangkan multimedia interaktif dengan Macromedia Authorware 7.0 pada matakuliah Konsep Dasar IPA - Pokok Bahasan Tata Surya.

2. Mengetahui hasil pembelajaran yang diselenggarakan dengan menggunakan multimedia interaktif dengan Macromedia Authorware 7.0 pada matakuliah Konsep Dasar IPA - Pokok Bahasan Tata Surya.

3. Menguji kelayakan multimedia interaktifdengan Macromedia Authorware 7.0 pada matakuliah Konsep Dasar IPA - Pokok Bahasan Tata Surya yang diujicobakan pada mahasiswa peserta perkuliahan Konsep Dasar IPA semester genap tahun akademik 2010-2011.

Pengembangan multimedia pembelajaran interaktif dengan Macromedia Authorware 7.0 Pada Matakuliah Konsep Dasar IPA - Pokok Bahasan Tata Surya bermanfaat:

1. Bagi para dosen S1 PGSD, memberikan suatu model pembelajaran interaktif yang mengacu pada struktur Kurikulum Program Studi S1 PGSD dengan menggunakan media pembelajaran interaktif Macromedia Authorware 7.0.

2. Bagi para mahasiswa S1 PGSD, meningkatkan kualitas pembelajaran yang berpusat pada mahasiswa (student oriented) yang di dalamnya mahasiswa akan mengalami proses menemukan.

\section{TINJAUAN PUSTAKA}

\section{Multimedia Pembelajaran Interaktif}

Yusufhadi Miarso dalam salah satu artikelnya memberikan batasan media pembelajaran sebagai segala sesuatu yang dapat digunakan untuk merangsang pikiran, perasaan, perhatian dan kemauan mahasiswa sehingga dapat mendorong terjadinya proses belajar dalam diri mahasiswa (Sopyan 2003:4). Secara sederhana, multimedia diartikan sebagai lebih dari satu media. Arti multimedia yang umumnya dikenal dewasa ini adalah berbagai macam kombinasi grafis, teks, suara, video, dan animasi. Penggabungan ini merupakan suatu kesatuan yang secara bersama-sama menampilkan informasi, pesan, atau isi pelajaran. Konsep penggabungan ini dengan sendirinya memerlukan beberapa jenis peralatan perangkat keras yang masing-masing tetap menjalankan fungsi utamanya sebagaimana biasanya, dan komputer merupakan pengendali seluruh peralatan itu. Multimedia bertujuan untuk menyajikan informasi dalam bentuk yang menyenangkan, menarik, mudah dimengerti, dan jelas. Multimedia berbasis komputer ini sangat menjanjikan untuk penggunaannya dalam bidang pendidikan (Arsyad, 2000:169-171).

\section{Aspek-aspek Media Pembelajaran Interaktif}

Media pembelajaran interaktif dikatakan baikjika memenuhi aspek-aspek penilaian terhadap media tersebut. Salah satu dari aspek itu adalah aspek komunikasi visual (Affandy, 2011) yang terdiri dari

1. Komunikatif; sesuai dengan pesan dan dapat diterima/sejalan dengan keinginan sasaran

2. Kreatif dalam ide berikut penuangan gagasan

3. Sederhana dan memikat 
4. Audio (narasi, sound effect, backsound,musik)

5. Visual (layout design, typography, warna)

6. Media bergerak (animasi, movie)

7. Layout Interactive (ikon navigasi)

\section{Macromedia Authorware 7.0}

Macromedia Authorware 7.0 merupakan software yang tepat untuk membuat berbagai bentuk sajian visual yang dapat mengintepretasikan berbagai media, seperti video, animasi, gambar dan suara. Sehingga program ini cukup memadai ketika digunakan dalam pembuatan berbagai macam aplikasi tutorial yang interaktif dan menarik. Dengan Macromedia Authorware 7.0 dapat dibuat program pembelajaran multimedia interaktif untuk mempresentasikan laporan pendidikan maupun laporan hasil penelitian ilmiah.

Macromedia Authorware 7.0 mempunyai fasilitas yang lengkap, penggunaannya pun mudah, antara lainuntuk:

1. Mengimpor file, gambar, suara, dan movie,

2. Membuat menu pilihan dan animasi sederhana,

3. Membuat lompatan dari tampilan satu ke tampilan lain,

4. Membuat kuis dan game,

5. Membuat respon dan menampilkan hasil tes (evaluasi).

Authorware adalah authoring tool yang berbasis icon yang memungkinkan kita dapat mengembangkan berbagai aplikasi multimedia interaktif. Program ini juga didukung beberapa software animasi, grafis, dan sound (suara) yang bisa dikombinasikan menjadi suatu tampilan multimedia yang berkualitas. Software-software tersebut antara lain: Macromedia Flash MX, Director MX, Quick Time, Adobe Photoshop, Corel Draw, Cool Edit, dan sebagainya.

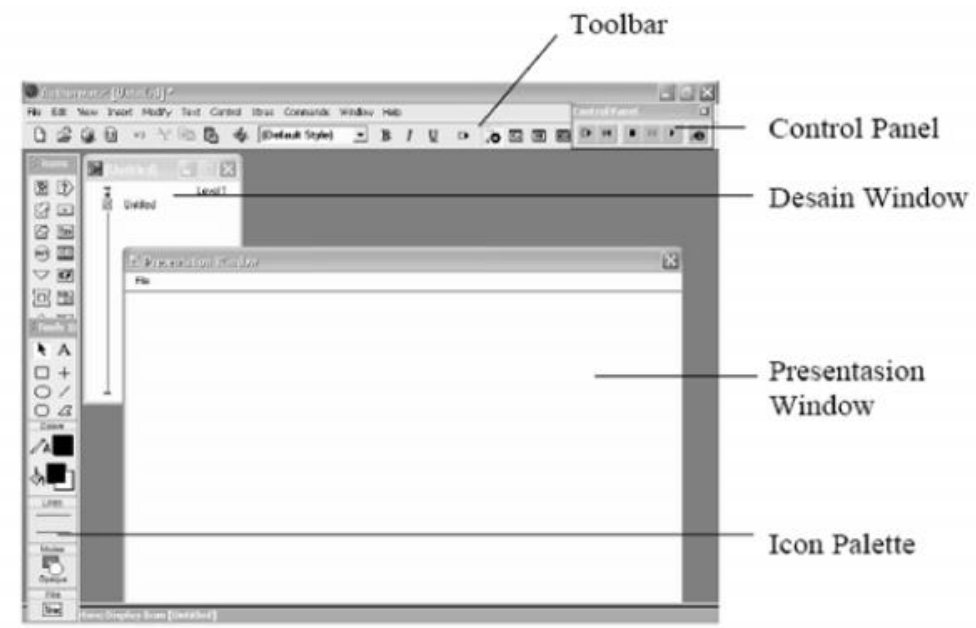

Gambar 1. Jendela Untuk Menampilkan Presentasi

Komponen utama yang sangat penting dalam pembuatan presentasi/tutorial dengan menggunakan Macromedia Authorware adalah adalah pembuatan flowline map dan interaksi antara program dan user. Meskipun sebenarnya Macromedia Authorware memiliki beragam menu dan submenu. 
Flowline map hakikatnya adalah sebuah desain yang memberikan gambaran utuh/lengkap presentasi atau tutorial yang akan dibuat.

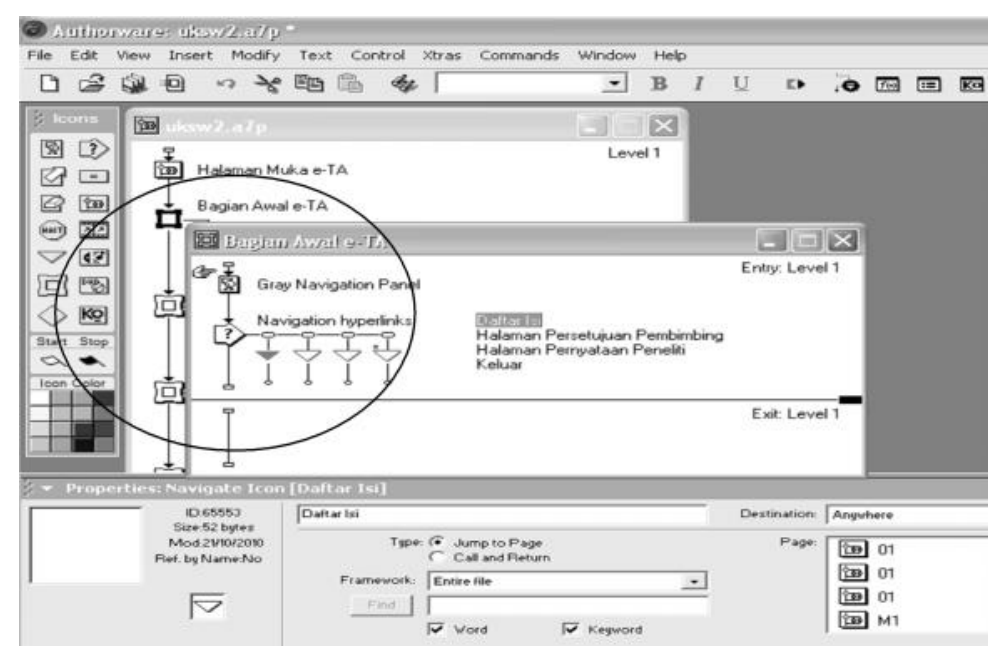

Gambar 2. Contoh flowline map Bagian Awal e-portofolio e-TA

Dalam merancang flowline map, misalnya flowline map mengikuti langkah-langkah sebagai berikut:

a) Klik menu File $>$ New $>$ File atau tekan tombol Ctrl+N untuk membuat file Authorware baru. Lihat Gambar 5.

b) Klik dan drag ikon Display pada palet Icons ke dalam flowline.

c) Klik dan drag salah satu icon, tahan dan geser ke garis flowline.

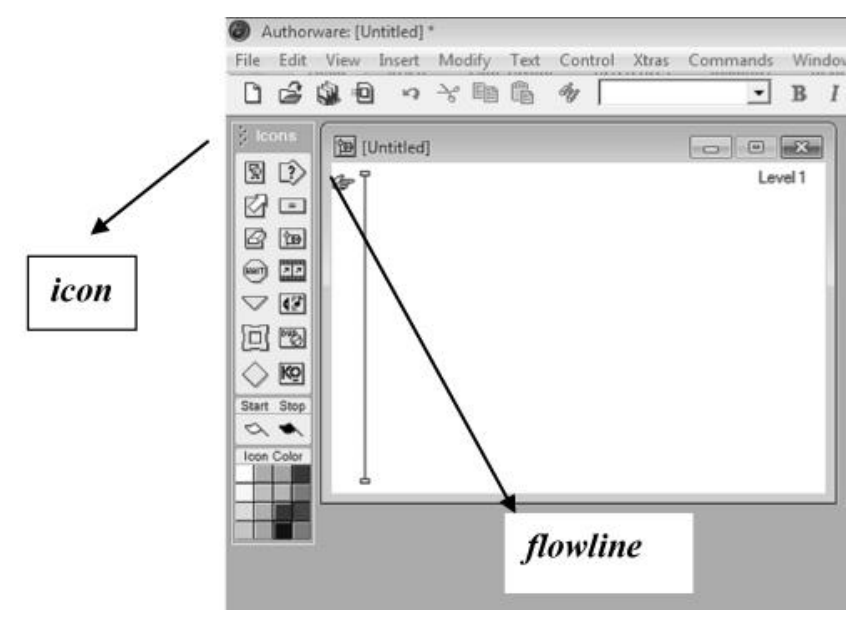

Gambar 3. Langkah membuat flowline

\section{METODE PENELITIAN}

\section{Desain Penelitian}

Sesuai dengan tujuan penelitian, desain penelitian yang digunakan adalah desain penelitian pengembangan. Prosedur pengembangan dalam penelitian mengadaptasi model pengembangan menurut Dick \& Carey dan juga Nana Syaodih Sukmadinata (2007:184-185). Prosedur yang diadaptasi tersebut 
meliputi tiga tahap yaitu (1) tahap studi pendahuluan, (2) tahap penyusunan draft produk dan (3) tahap pengembangan dan evaluasi. Secara diagramatis langkah-langkah ini digambarkan sebagai berikut:

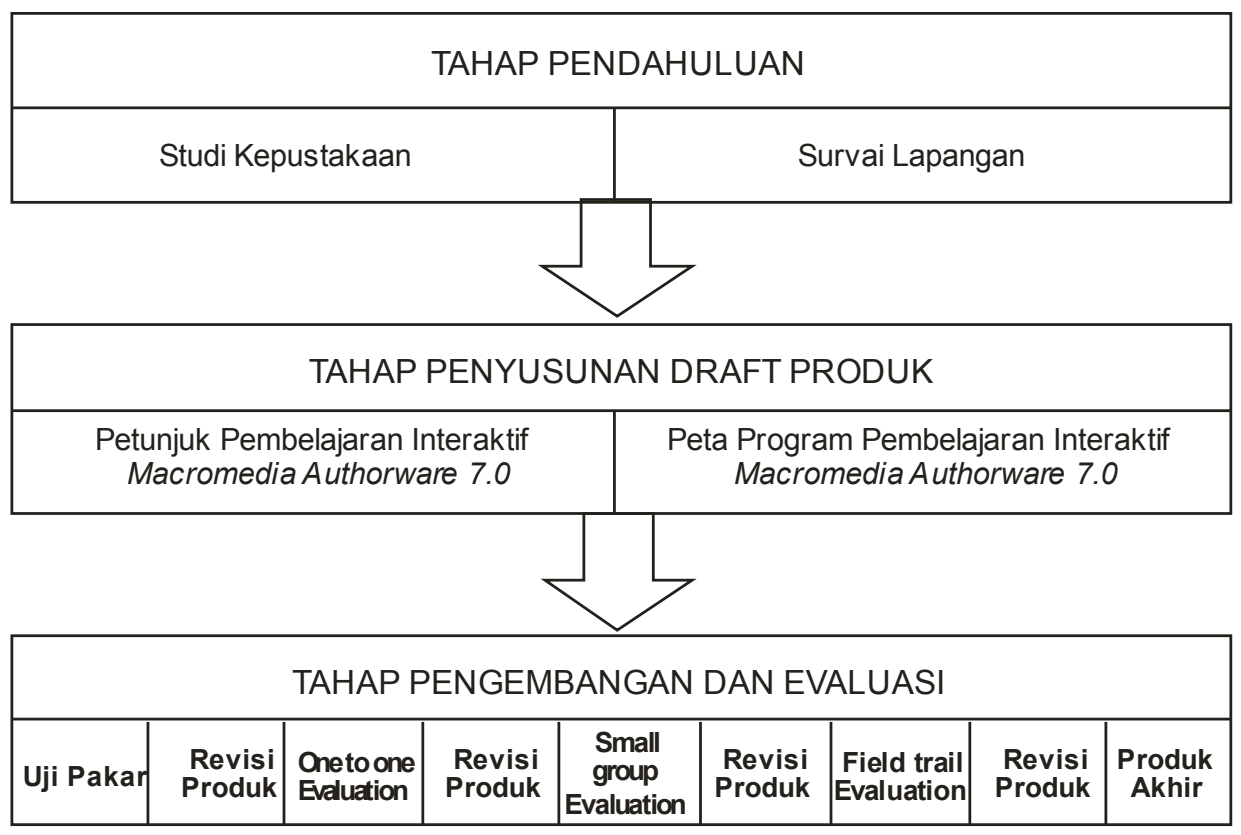

Gambar 4. Tahapan Penelitian dan Pengembangan

\section{Tahap Studi Pendahuluan}

Tahap ini merupakan tahap pertama atau persiapan untuk pengembangan. Tahap ini terdiri dari studi kepustakaan dan survai lapangan. Pada tahap studi kepustakaan, peneliti melakukan kajian terhadap konsep-konsep atau teori-teori yang berkenaan dengan multimedia pembelajaran interaktif dan Macromedia Authorware 7.0. Kajian juga dilakukan terhadap hakikat matakuliah Konsep Dasar IPA. Komponenkomponen yang dicermati dalam studi pendahuluan mencakup juga standar kompetensi, kompetensi dasar maupun materi pelajaran sebagai landasan pengembangan multimedia pembelajaran interaktif dan Macromedia Authorware 7.0. Selain itu juga dilakukan kajian terhadap hasil-hasil penelitian yang berkenaan dengan pembelajaran interaktif dengan Macromedia Authorware 7.0.

\section{Tahap Penyusunan Draft Produk}

Berdasarkan pada studi kepustakaan mengenai dasar-dasar teori dan konsep mengenai Macromedia Authorware 7.0 serta survai lapangan, maka peneliti menyusun draft awal produk yaitu multimedia pembelajaran interaktif yang akan dikembangkan. Pada tahap ini langkah-langkah pembelajaran dengan Macromedia Authorware 7.0 dirancang dengan didasarkan pada analisis kebutuhan di atas. Hasilnya adalah draft produk awal berupa media pembelajaran interaktif dengan Macromedia Authorware 7.0 sebagai multimedia pembelajaran dalam mata kuliah Konsep Dasar IPA. Multimedia ini juga menggunakan animasi yang disediakan oleh Jelajah Antariksa tentang tata surya.

\section{Tahap Pengembangan dan Evaluasi}

Uji coba yang dilakukan berdasarkan adaptasi dari Dick \& Carey dan juga Sukmadinata (2007:184) yang meliputi empat tahap yaitu uji pakar (expert judgment), uji coba satu lawan satu (one to one evaluation), uji coba kelompok kecil (small group evaluation) dan uji coba lapangan (field trial 
evaluation). Uji pakar dilakukan untuk menguji kelayakan produk berupa model CD Pembelajaran sebelum diujicoba di lapangan. Pada tahap uji coba satu lawan satu, uji coba kelompok kecil dan uji coba lapangan dilakukan uji coba pemakaian multimedia pembelajaran interaktif ini. Hasil ini kemudian dipakai sebagai dasar evaluasi untuk memperbaiki produk sehingga dihasilkan produk akhir.

\section{Uji Coba Produk}

\section{Desain Uji Coba}

Uji coba yang dilakukan bertujuan untuk menyempurnakan model pembelajaran dengan mempraktekkan secara langsung di lapangan. Uji coba yang dilakukan didasarkan adaptasi dari Dick \& Carey dan juga Sukmadinata (2007:184) yang meliputi tiga tahap yaitu:

a. Uji pakar/ahli (expertjudgment)

Uji pakar atau ahli dilakukan oleh pakar multimedia pembelajaran untuk menilai dan memberikan masukan terhadap draft produk awal. Uji pakar ini untuk memvalidasi produk sebelum dilakukan uji coba di lapangan.

b. Uji coba satu lawan satu (one to one evaluation)

Uji coba satu lawan satu ini dilakukan pada 3 orang mahasiswa yang mengikuti mata kuliah Konsep Dasar IPA. Pada pelaksanaan uji coba ini, para mahasiswa mencoba menggunakan multimedia pembelajaran interaktif, mengisi angket dan juga mengerjakan soal evaluasi untuk mengetahui tingkat pemahaman atas materi yang dipelajari.

c. Uji coba kelompok kecil (small group evaluation)

Uji coba ini hampir mirip dengan uji coba satu lawan satu, bedanya pada tahap ini, mahasiswa yang dilibatkan lebih banyak (20 orang). Mahasiswa mencoba menggunakan multimedia pembelajaran interaktif, mengisi angket dan juga mengerjakan soal evaluasi. Hasil dari data kuesioner dikumpulkan dan dianalisis yang kemudian digunakan untuk merevisi produk.

d. Uji coba lapangan (field trial evaluation)

Uji coba luas diterapkan pada 1 kelas penuh mata kuliah Konsep Dasar IPA. Kegiatan yang dilakukan hampir mirip dengan kegiatan yang dilakukan pada uji coba sebelumnya. Perbedaannya adalah pada uji coba ini, subjek uji cobanya lebih banyak dan lebih luas, yaitu satu kelas yang terdiri dari 40 orang. Data kuantitatif yaitu kemampuan sebelum dan sesudah menggunakan pembelajaran (pre test dan post test) dikumpulkan untuk dianalisis.

\section{Subjek Uji Coba}

Subjek uji coba dalam penelitian pengembangan ini adalah sebagai berikut:

a. Uji pakar/ahli: 1 orang pakar multimedia pembelajaran yang berkompeten di dalam Pembelajaran interaktif dengan Macromedia Authorware 7.0

b. Uji coba satu lawan satu (one to one evaluation): 3 orang mahasiswa yang menempuh matakuliah Konsep Dasar IPA

c. Uji coba kelompok kecil (small group evaluation): 20 orang mahasiswa yang menempuh matakuliah Konsep Dasar IPA

d. Uji coba lapangan (field trial evaluation): 1 kelas (40 orang) mata kuliah Konsep Dasar IPA. 
Jenis Data

Jenis data yang diperoleh dalam penelitian dan pengembangan ini berupa data kualitatif dan data kuantitatif. Data kualitatif berasal dari masukan dari pakar pembelajaran dan hasil angket dari mahasiswa. Data kuantitatif diperoleh dari penilaian pakar pembelajaran terhadap draft produk, pre test dan post test. Data-data tersebut digunakan untuk mengevaluasi pengembangan multimedia pembelajaran interaktifdengan Macromedia Authorware 7.0.

Instrumen Pengumpulan Data

Instrumen pengumpulan data pada penelitian ini digunakan untuk mengumpulkan data pada uji validitas dari pakar, uji coba satu lawan satu, uji coba kelompok kecil dan uji coba lapangan. Uji validitas pakar menggunakan instrumen lembar validasi pakar pembelajaran. Uji coba satu lawan satu, uji coba kelompok kecil dan uji coba lapangan menggunakan instrumen angket dan tes. Fungsi dari instrumen tersebut adalah sebagai berikut:

a. Lembar validasi pakar pembelajaran

Lembar validasi dari pakar pembelajaran digunakan untuk memvalidasi draft produk awal yang telah dibuat sehingga layak untuk diuji coba.

b. Angket

Angket digunakan untuk mengumpulkan data tentang penilaian mahasiswa terhadap multimedia pembelajaran interaktif dengan Macromedia Authorware 7.0.

c. Tes

Tes pada penelitian ini berupa soal evaluasi untuk mengukur kemampuan mahasiswa memahami materi yang disajikan dalam multimedia pembelajaran interaktif.

\section{Teknik Analisis Data}

Analisis terhadap data adalah dengan menggunakan teknik analisis deskriptif. Frekuensi tiap-tiap skor dihitung untuk mengetahui persentase dari kategori sangat baik (5), baik (4), cukup (3), kurang (2) dan sangat kurang (1).

\section{HASIL PENELITIAN}

\section{Data Uji Coba}

Data hasil uji coba Multimedia Pembelajaran Interaktif dengan Macromedia Authorware 7.0 Pada Matakuliah Konsep Dasar IPA ini terdiri dari (1) hasil validasi dari pakar multimedia pembelajaran, (2) hasil one to one evaluation, (3) hasil small group evaluation dan (4) hasil field trial evaluation.

\section{Hasil Validasi dari Pakar (Expert Judgment)}

Setelah draft produk awal dirancang, maka sebelum diujicobakan, draft produk awal ini direview atau divalidasi oleh pakar pembelajaran. Pakar pembelajaran yang memvalidasi Multimedia Pembelajaran Interaktif dengan Macromedia Authorware 7.0 Pada Matakuliah Konsep Dasar IPA di sini adalah pakar multimedia pembelajaran di bidang pembelajaran IPA. Hasil validasi dari pakar multimedia pembelajaran dapat dilihat pada Tabel 1 
Tabel 1. Hasil Validasi dari Pakar Multimedia Pembelajaran

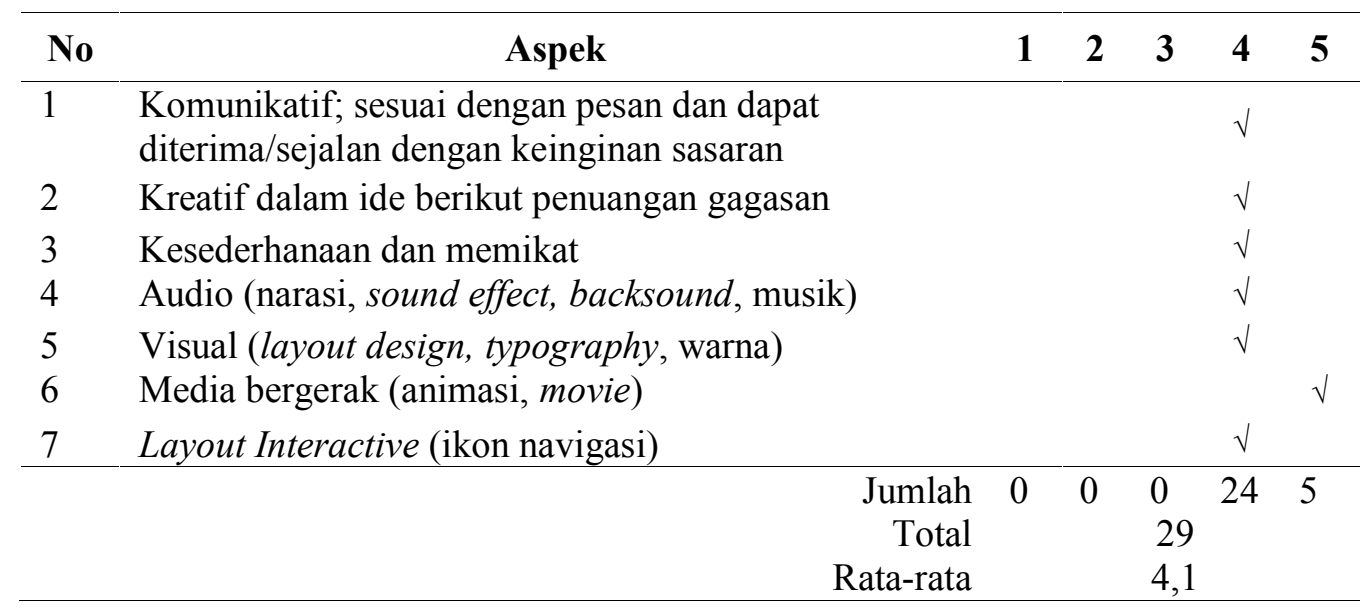

Secara umum draft produk awal ini sudah baik dengan melihat skor penilaian untuk sebagian besar indikator berada pada nilai 4 (baik) dan ada indikator pada nilai 5 (sangat baik). Jumlah total nilai dari lembar validasi oleh pakar adalah 29 dan rata-ratanya adalah 4,1 termasuk dalam kategori baik.

\section{Hasil One to One Evaluation}

Berikut adalah data yang diperoleh dari one to one evaluation, yaitu berupa data angket dari mahasiswa. Hasil uji coba pada one to one evaluation menunjukkan bahwa skor yang diberikan oleh mahasiswa pada uji ini rata-rata berada pada nilai 4. Aspek komunikatif berada pada nilai 3.7. Sedangkan aspek kreatifitas, kesederhanaan, visual, media bergerak dan layout interactive berada pada skor antara 4.3 sampai 4.7. Nilai terendah untuk aspek audio berada pada nilai 3.0.

\section{Hasil Small Group Evaluation}

Berikut adalah data yang diperoleh dari uji small group evaluation, yaitu berupa data angket dari mahasiswa.

Tabel 2. Hasil dari One to One Evaluation

\begin{tabular}{|c|c|c|}
\hline No & Aspek & Skor \\
\hline 1 & Komunikatif; & 3.7 \\
\hline 2 & Kreatif dalam ide berikut penuangan gagasan & 4.7 \\
\hline 3 & Kesederhanaan dan memikat & 4.3 \\
\hline 4 & Audio (narasi, sound effect, backsound, musik) & 3.0 \\
\hline 5 & Visual (layout design, typography, warna) & 4.7 \\
\hline 6 & Media bergerak (animasi, movie) & 4.7 \\
\hline \multirow[t]{3}{*}{7} & Layout Interactive (ikon navigasi) & 4.3 \\
\hline & Jumlah & 29.3 \\
\hline & Rata-rata & 4.2 \\
\hline
\end{tabular}

Hasil uji coba pada small group evaluation menunjukkan bahwa skor yang diberikan oleh mahasiswa pada uji ini rata-rata berada pada nilai 4. Aspek komunikatif, kreativitas, kesederhanaan, visual, media bergerak dan layout interactive berada pada skor antara 4.0 sampai 4.3. Nilai untuk aspek audio berada pada nilai 3.9 mendekati nilai 4.0 . 
Tabel 3. Hasil dari Small Group Evaluation

\begin{tabular}{|c|c|c|}
\hline No & Aspek & Skor \\
\hline 1 & Komunikatif & 4.1 \\
\hline 2 & Kreatif dalam ide berikut penuangan gagasan & 4.2 \\
\hline 3 & Kesederhanaan dan memikat & 4.0 \\
\hline 4 & Audio (narasi, sound effect, backsound, musik) & 3.9 \\
\hline 5 & Visual (layout design, typography, warna) & 4.3 \\
\hline 6 & Media bergerak (animasi, movie) & 4.3 \\
\hline \multirow[t]{3}{*}{7} & Layout Interactive (ikon navigasi) & 4.1 \\
\hline & Jumlah & 28.7 \\
\hline & Rata-rata & 4.1 \\
\hline
\end{tabular}

\section{Hasil Field Trial Evaluation}

Berikut adalah data yang diperoleh dari uji field trial evaluation, yaitu berupa data angket dari mahasiswa.

Hasil uji coba pada field trial evaluation menunjukkan bahwa skor yang diberikan oleh mahasiswa pada uji ini rata-rata berada pada nilai 4.2. Seluruh aspek komunikatif, kreatifitas, kesederhanaan, audio, visual, media bergerak, dan layout interactive berada pada nilai 4.0 sampai 4.4 .

Tabel 4. Hasil dari Field Trial Evaluation

\begin{tabular}{|c|c|c|}
\hline No & Aspek & Skor \\
\hline 1 & Komunikatif & 4.2 \\
\hline 2 & Kreatif dalam ide berikut penuangan gagasan & 4.3 \\
\hline 3 & Kesederhanaan dan memikat & 4.2 \\
\hline 4 & Audio (narasi, sound effect, backsound, musik) & 4.0 \\
\hline 5 & Visual (layout design, typography, warna) & 4.4 \\
\hline 6 & Media bergerak (animasi, movie) & 4.4 \\
\hline \multirow[t]{3}{*}{7} & Layout Interactive (ikon navigasi) & 4.2 \\
\hline & Jumlah & 29.7 \\
\hline & Rata-rata & 4.2 \\
\hline
\end{tabular}

\section{Hasil Tes}

Hasil pemahaman mahasiswa mengenai materi tata surya dilakukan melalui tes. Tes yang diberikan kepada mahasiswa mencakup beberapa hal seputar tata surya, yaitu anggota tata surya, ciri-ciri masingmasing anggota tata surya, planet terbesar, planet terkecil dan planet yang memiliki cincin. Adapun ratarata hasil tes untuk tiap-tiap uji coba disajikan pada Tabel 5 berikut.

Tabel 5. Hasil Tes

\begin{tabular}{rlccc}
\hline \multirow{2}{*}{ No. } & \multicolumn{1}{c}{ Tahap } & $\begin{array}{c}\text { Jumlah } \\
\text { Mahasiswa }\end{array}$ & \multicolumn{2}{c}{ Nilai Rata-rata } \\
& & 3 & 52 & 78 \\
\hline 1 & One to one evaluation & 20 & 46 & 84 \\
2 & Small group evaluation & 40 & 53 & 86 \\
3 & Field trial evaluation & & 50.3 & 82.7 \\
\hline \multicolumn{2}{r}{ Rata-rata } \\
\hline
\end{tabular}




\section{Analisis Data}

1. Analisis Data dari Validasi Pakar Pembelajaran

Secara umum penilaian yang diberikan oleh pakar multimedia pembelajaran menunjukkan hasil yang baik. Multimedia ini sudah menunjukkan unsur komunikatif. Pesan yang disampaikan dari multimedia ini bisa menunjukkan maksud dari materi yang disampaikan. Kreatifitas dalam multimedia ini juga sudah baik. Demikian juga dari aspek kesederhanaan, audio, visual, media bergerak dan layout interactive sudah baik. Validasi dari pakar multimedia pembelajaran menunjukkan bahwa draft Multimedia Pembelajaran Interaktif ini sudah valid dan dapat dilanjutkan dengan uji coba kepada mahasiswa.

\begin{tabular}{ccccl}
\hline Tabel 6 Distribusi Frekuensi Hasil Validasi Pakar Multimedia Pembelajaran \\
\hline $\begin{array}{c}\text { Skala Likert } \\
\text { (n) }\end{array}$ & $\begin{array}{c}\text { Frekuensi } \\
(\mathbf{F})\end{array}$ & F.n & $\begin{array}{c}\text { Persentase } \\
(\mathbf{\% )}\end{array}$ & \multicolumn{1}{c}{ Kategori } \\
\hline 5 & 1 & 5 & 14.3 & Sangat bagus \\
4 & 6 & 24 & 85.7 & Bagus \\
3 & 0 & 0 & 0.0 & Cukup \\
2 & 0 & 0 & 0.0 & Kurang \\
1 & 0 & 0 & 0.0 & Sangat kurang \\
\hline Jumlah & 7 & 29 & 100.0 & \\
Rata-rata & 4,1 & & & \\
\hline
\end{tabular}

\section{Analisis Data One to One Evaluation}

Data yang didapat dari one to one evaluation menunjukkan bahwa aspek komunikatif, kreatif, kesederhanaan, visual, media bergerak dan layout interactive sudah baik. Hal yang perlu mendapat perhatian adalah audio. Audio mendapat penilaian yang rendah daripada aspek yang lain. Berdasarkan masukan dari mahasiswa yang mengikuti uji ini adalah volume suara dari multimedia ini kurang jelas. Setelah dikaji ulang, hal ini disebabkan karena perangkat pengeras suara (loudspeaker) dari perangkat komputer yang kurang mendukung atau kurang keras.

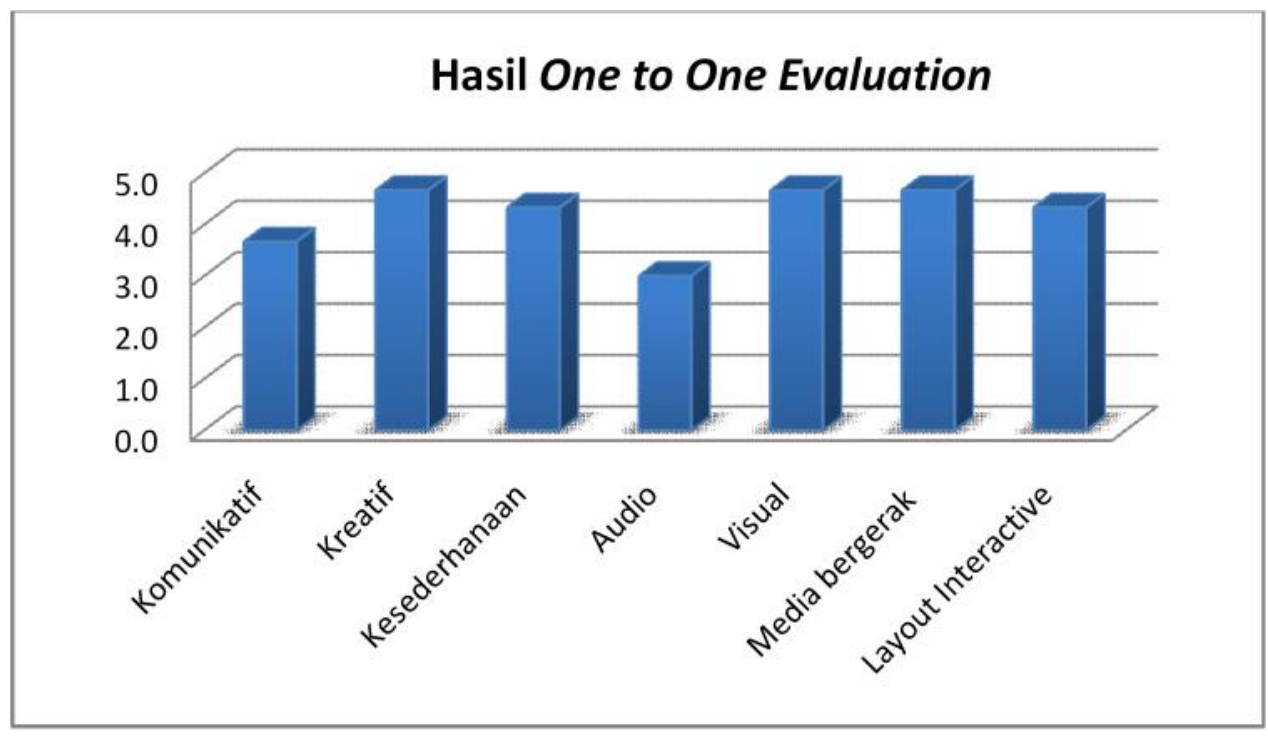

Gambar 5 Diagram Batang Hasil One to One Evaluation 
Berdasarkan data yang diperoleh sebelumnya dapat dikelompokkan skor dari uji coba pertama seperti yang disajikan pada tabel 7. Hasil skor 5 menunjukkan persentase sebesar 38,1 persen; skor 4 sebesar 42,9 persen dan skor 3 sebesar 19 persen. Secara umum rata-rata nilai yang diberikan pada multimedia interaktif ini sebesar 4.2 berada pada kategori baik.

Tabel 7 Distribusi Frekuensi Hasil One to One Evaluation

\begin{tabular}{ccccl}
\hline $\begin{array}{c}\text { Skala Likert } \\
(\mathbf{n})\end{array}$ & $\begin{array}{c}\text { Frekuensi } \\
(\mathbf{F})\end{array}$ & F.n & $\begin{array}{c}\text { Persentase } \\
(\%)\end{array}$ & \multicolumn{1}{c}{ Kategori } \\
\hline 5 & 8 & 40 & 38.1 & Sangat bagus \\
4 & 9 & 36 & 42.9 & Bagus \\
3 & 4 & 12 & 19.0 & Cukup \\
2 & 0 & 0 & 0.0 & Kurang \\
1 & 0 & 0 & 0.0 & Sangat kurang \\
\hline Jumlah & 21 & 88 & 100 & \\
Rata-rata & 4.2 & & & \\
\hline
\end{tabular}

\section{Analisis Data Small Group Evaluation}

Data yang didapat dari small group evaluation menunjukkan bahwa aspek komunikatif, kreatif, kesederhanaan, visual, media bergerak dan layout interactive berada pada skor 4 . Aspek audio sudah meningkat tetapi belum maksimal. Berdasarkan masukan dari mahasiswa yang mengikuti uji ini adalah volume suara dari multimedia ini kurang jelas. Perangkat pengeras suara (loudspeaker) dari perangkat komputer kurang mendukung atau kurang keras. Sedangkan aspek kesederhanaan dinilai mendekati skor 4 karena menurut mahasiswa, multimedia ini diasumsikan sudah lebih dari sekedar sederhana. Sehingga pemahaman mahasiswa mengenai aspek ini tidak masalah.

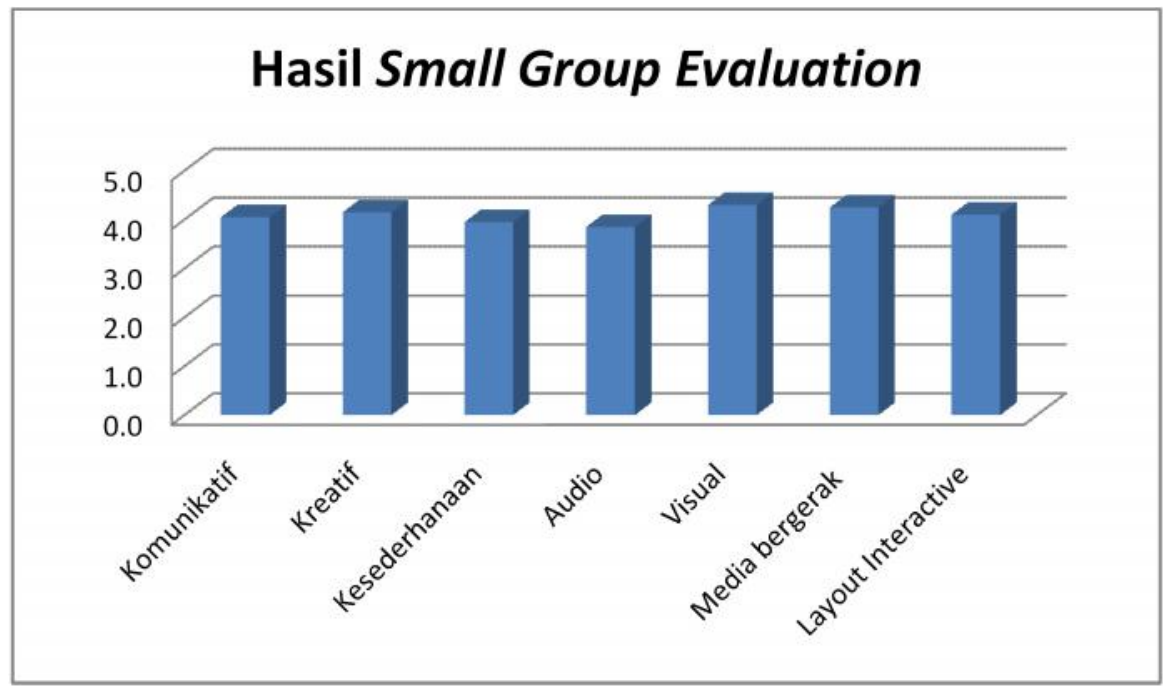

Gambar 6. Diagram Batang Hasil Small Group Evaluation

Berdasarkan data yang diperoleh pada uji coba kedua ini dapat dilihat dalam Tabel 8 . Hasil dari tabel tersebut menunjukkan bahwa skor 5 menunjukkan persentase sebesar 24.3 persen; skor 4 sebesar 62.1 persen dan skor 3 sebesar 12.1 persen. Secara umum rata-rata nilai yang diberikan pada multimedia interaktif ini sebasar 4.1 berada pada kategori baik. 
Tabel 8 Distribusi Frekuensi Hasil Small Group Evaluation

\begin{tabular}{ccccl}
\hline Skala Likert (n) & $\begin{array}{c}\text { Frekuensi } \\
(\mathbf{F})\end{array}$ & F.n & $\begin{array}{c}\text { Persentase } \\
(\mathbf{\%})\end{array}$ & \multicolumn{1}{c}{ Kategori } \\
\hline 5 & 34 & 170 & 24.3 & Sangat bagus \\
4 & 87 & 348 & 62.1 & Bagus \\
3 & 17 & 51 & 12.1 & Cukup \\
2 & 2 & 4 & 1.4 & Kurang \\
1 & 0 & 0 & 0.0 & Sangat kurang \\
\hline Jumlah & 140 & 573 & 100 & \\
Rata-rata & 4.1 & & & \\
\hline
\end{tabular}

\section{Analisis Data Field Trial Evaluation}

Uji coba terakhir yaitu field trial evaluation menunjukkan bahwa aspek komunikatif, kreatif, kesederhanaan, visual, media bergerak dan layout interactive berada pada skor 4 . Aspek audio sudah meningkat tetapi belum maksimal. Berdasarkan masukan dari mahasiswa yang mengikuti uji ini adalah volume suara dari multimedia ini kurang jelas. Berdasarkan pengamatan dari peneliti, selama mahasiswa mencoba menggunakan multimedia interaktif karena terdiri dari kelas besar (40 orang) kadang cukup ramai saat berdiskusi dalam kelompok.

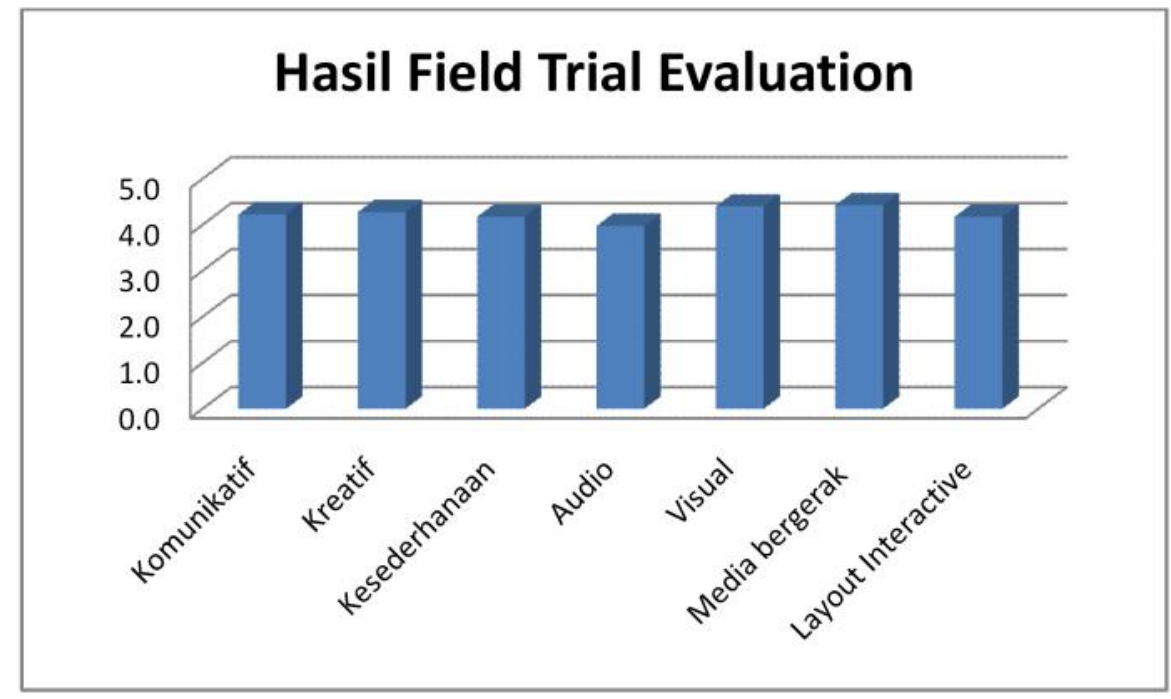

Gambar 7. Diagram Batang Hasil Field Trial Evaluation

Data yang diperoleh pada uji coba ketiga ini dapat dilihat dalam Tabel 9. Hasil dari tabel tersebut menunjukkan bahwa skor 5 menunjukan persentase sebesar 35.4 persen; skor 4 sebesar 53.9 persen dan skor 3 sebesar 9.6 persen. Secara umum rata-rata nilai yang diberikan pada multimedia interaktif ini sebesar 4.2 berada pada kategori baik. 
Tabel 9. Distribusi Frekuensi Hasil Field Trial Evaluation

\begin{tabular}{ccccl}
\hline $\begin{array}{c}\text { Skala Likert } \\
(\mathbf{n})\end{array}$ & $\begin{array}{c}\text { Frekuensi } \\
(\mathbf{F})\end{array}$ & F.n & $\begin{array}{c}\text { Persentase } \\
(\mathbf{\%})\end{array}$ & \multicolumn{1}{c}{ Kategori } \\
\hline 5 & 99 & 495 & 35.4 & Sangat bagus \\
4 & 151 & 604 & 53.9 & Bagus \\
3 & 27 & 81 & 9.6 & Cukup \\
2 & 3 & 6 & 1.1 & Kurang \\
1 & 0 & 0 & 0.0 & Sangat kurang \\
\hline Jumlah & 280 & 1186 & 100 & \\
Rata-rata & 4.2 & & & \\
\hline
\end{tabular}

\section{Analisis Data Tes}

Hasil tes yang dilakukan pada tiap-tiap uji coba menunjukkan adanya peningkatan nilai tes dari pre test ke post test. Rata-rata nilai pre test adalah 50 sedangkan rata-rata post test adalah 80 . Hal ini menunjukkan bahwa multimedia interaktif ini membuat pemahaman dan penguasaan materi dari mahasiswa dapat meningkat.

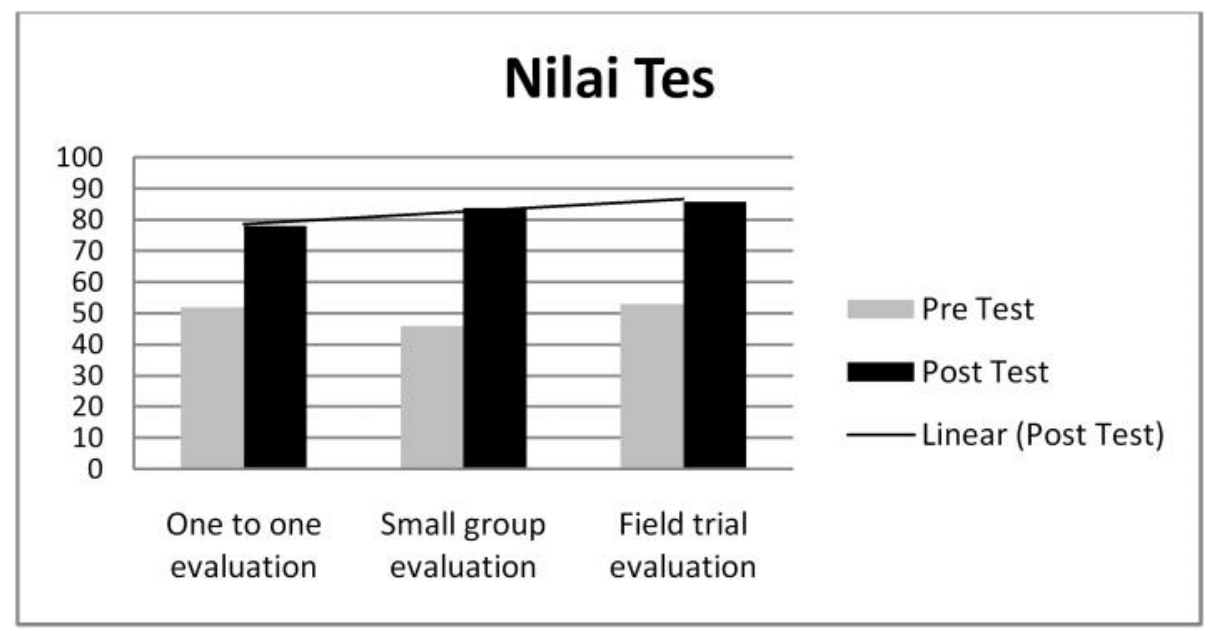

Gambar 8. Diagram Batang Hasil Tes

\section{Kajian Produk Akhir}

Produk yang dihasilkan dari penelitian pengembangan ini adalah multimedia pembelajaran interaktif authorware untuk pokok bahasan tata surya. Multimedia ini berisi materi tentang anggota-anggota tata surya dengan data-data dari masing-masing anggota tata surya tersebut. Gambar dan animasi menggambarkan bentuk dan penampakan dari anggota tata surya.

Hasil uji coba yang dilakukan melalui beberapa tahap. Uji coba dimulai dari validasi pakar multimedia pembelajaran kemudian dilanjutkan uji coba one to one evaluation, small group evaluation dan field trial evaluation. Hasil uji coba menunjukkan bahwa multimedia ini layak untuk digunakan dalam pembelajaran IPA khususnya pada topik atau pokok bahasan tata surya. Subjek uji coba menilai multimedia ini berada pada kategori baik. 


\section{PENUTUP}

1. Multimedia interaktif dengan Macromedia Authorware 7.0 pada matakuliah Konsep Dasar IPA Pokok Bahasan Tata Surya dapat dikembangkan dengan menyajikan animasi tentang tata surya dengan dilengkapi dengan data-data pendukung mengenai anggota tata surya tersebut.

2. Hasil tes dari pembelajaran dengan menggunakan multimedia interaktif dengan Macromedia Authorware 7.0 pada Matakuliah Konsep Dasar IPA-Pokok tata surya menunjukkan hasil yang baik. Hasil post tes rata-rata adalah 82.7 sedangkan hasil pre test adalah 50.3.

3. Multimedia interaktif dengan Macromedia Authorware 7.0 pada matakuliah Konsep Dasar IPA Pokok Bahasan Tata Surya ini layak untuk digunakan dalam pembelajaran. Hal ini terbukti dari hasil uji coba multimedia ini yang berada pada kategori baik pada tiap-tiap uji coba. Rata-rata skor pada one to one evaluation adalah 4.2; pada small group evaluation adalah 4.1 dan pada field trial evaluation adalah 4.2.

\section{DAFTAR PUSTAKA}

Affandy. 2011. Aspek dan Kriteria Penilaian Media Pembelajaran. http://affandy8591.wordpress.com/ 2009/08/07/aspek-dan-kriteria-penilaian-media-pembelajaran/

Carliner, S. 1999. Overview of online learning. Amherst. MA: Human Resource Development Press.

Cloete, Elsabe, 2000. Electronic education system model. Department of Computer Science and Information Systems, South Africa.

Dick, W. and Carey, L. 1996. The Systematic Design of Instruction. New York: Harper Collin Publishers.

Herman Dwi Surjono. 2007. Pengembangan E-learning dengan Moodle.

Harry B. Santoso, 2006. e-Learning: Belajar Kapan Saja, Dimana Saja.

Imam Subandi, Siregar Nelson. 2006: Mengembangkan ICT melalui tenaga Kependidikan. Jurnal Tenaga Kependidikan. Dirjen PMPTK Depdiknas.

Khan, B. 1997. Web-based instruction: What is it and why is it? In B. H. Khan (Ed.), Web-based instruction (pp. 5-18). Englewood Cliffs, NJ: Educational Technology Publications.

Raab Robert T., Ellis W. Wyn, Abdon Buenafe R 200. Internet and Higher Education 4 (2002) $217-$ 229 Multisectoral partnerships in e-learning A potential force for improved human capital development in the Asia Pacific. Bangkok 10900, Thailand.

Soekartawi, 2007. Merancang dan Menyelenggarakan e-Learning. Ardana Media bekerjasama dengan Rumah Produksi Informatifka, Yogyakarta.

Sukmadinata, Nana Syaodih. 2007. Metode Penelitian Pendidikan. Remaja Rosda Karya. 